Jadwiga Linde-Usiekniewicz

DOI: $10.33896 /$ PorJ.2019.9.2

(Uniwersytet Warszawski,

e-mail: jlindeus@uw.edu.pl)

\title{
POLSKIE ZDANIA WZGLĘDNE Z WEWNĘTRZNYM RZECZOWNIKIEM - WSTĘPNE ROZPOZNANIE
}

\section{WPROWADZENIE}

Przedmiotem przedstawionych tu rozważań są zdania względne, których formalna charakterystyka polega na tym, że w ich obrębie pojawia się rzeczownik nawiazujacy lub odnoszący się do rzeczownika lub grupy nominalnej w zdaniu głównym, np.:

(1) Piasecki był nacjonalista i przeciwnikiem "demoliberatów", która to nazwa, nieco mglista, obejmowała tych, którzy głosowali na pierwszego prezydenta Polski, Gabriela Narutowicza [Czesław Miłosz, Abecadło Miłosza, za: Bańko 2013, wyróżnienie własne].

W przytoczonym zdaniu rzeczownik nazwa odnosi się do wprowadzonego wcześniej w cudzysłowie określenia demoliberałowie. W zdaniach takich, inaczej niż w typowych zdaniach względnych, gdzie zaimek który zastępuje koreferencyjną $z$ nim grupę nominalna $\mathrm{w}$ zdaniu nadrzędnym [por. Grzegorczykowa 2004, 122], tę funkcję przejmuje rzeczownik (tu: nazwa). Również inaczej niż w typowych zdaniach względnych, zaimek który nie jest akomodowany pod względem liczby i rodzaju do rzeczownika w zdaniu nadrzędnym [por. Grzegorczykowa 2004, 122]. Przeciwnie, jest akomodowany jedynie do rzeczownika wewnattrz zdania względnego. Inna formalna cecha opisywanych tu zdań jest konieczność pojawienia się elementu to bezpośrednio po ciagu któr-. Występowanie takiego ciagu nie jest ograniczone wyłącznie do analizowanych tu zdań. Pojawia się on także w zdaniach bez wewnętrznego rzeczownika, np.:

(2) Pomysł na stworzenie żłóbka bożonarodzeniowego przypisuje się św. Franciszkowi $z$ Asyżu, który to $w 1223$ stworzył stajenke ze żłóbkiem i zwierzętami [Narodowy Korpus Języka Polskiego - NKJP, podkreślenie własne]. 
Niemniej w zdaniach typu (1) pojawienie się ciagu to wydaje się we współczesnej polszczyźnie obligatoryjne, ${ }^{1}$ nie jest natomiast obowiąkowe w zdaniach typu (2), w których forma przypadkowo-liczbowa zaimka względnego akomodowana jest do rzeczownika należącego do zdania nadrzędnego. ${ }^{2}$

Zwraca uwage fakt, iż zdania typu (2) rzadko sa - na tyle, na ile mogłam to ustalić - przedmiotem opisu gramatycznego. Nie wspomina się o nich w opracowaniach ogólnoskładniowych - ani klasycznych, takich jak Zenona Klemensiewicza [1953], ani nowszych, jak np. cytowany już podręcznik Renaty Grzegorczykowej [2004] czy oparta na wyczerpującym przeglądzie literatury praca Adama Przepiórkowskiego et al. [2002]. Brak także odniesień do takich zdań w pracach poświęconych w całości zdaniom względnym, zarówno $\mathrm{w}$ ujęciu teoretycznym, np. klasyczna praca Leona Zawadowskiego [1952], jak i opisowym, np. w pracy Alicji Stypki [1995]. Co ciekawe, w cytowanym tu artykule A. Stypki pojawiaja się jako przykłady zdania typu (1), a mianowicie:

(3) $W$ dniu $10 \mathrm{bm}$. w późnych godzinach wieczornych Papież Jan Paweł II odleciał samolotem z lotniska Flumicino do Argentyny, który to kraj jest celem jego XIII podróży apostolskiej [S[łowo] P[owszechne], Stypka 1995, 24].

(4) Młodzież właczy się $w$ prace polowe, $z$ którego to zadania postara się wywiazać należycie [Stypka 1995, 26].

Jednak autorka nie zwraca uwagi na ich odrębność gramatyczna.

Jednym $z$ wyjątków, jeżeli chodzi o prace powstałe w języku polskim, jest tekst Zuzanny Topolińskiej [1984], ${ }^{3} \mathrm{w}$ którym konstrukcje takie sa wprost wymienione i analizowane wśród innych konstrukcji względnych.

Zdania względne $z$ który to, ale jedynie typu (1), już nie typu (2), czyli zdania $z$ wewnętrznym rzeczownikiem, stanowia temat artykułu Imke Mendozy [2010]. Badaczka ta również zwraca uwagę na pomijanie interesującego nas zjawiska $\mathrm{w}$ gramatykach opisowych. ${ }^{4}$ Jawne twierdzenie na temat zdań $z$ wewnętrznym rzeczownikiem we współczesnej polsz-

1 Inaczej niż we wcześniejszych epokach, o czym dalej.

2 Pozostawiam tu otwarta kwestię, czy sekwencja któr-to reprezentuje zaimek względny odrębny od zaimka który, występujacy tylko w zdaniach względnych nierestrykcyjnych (o czym dalej), czy połączenie zaimka względnego który i partykuły to. Rozważania takie, podobnie jak opis zdań typu (2), będą przedmiotem odrębnych opracowań.

3 Kolejnym wyjątkiem jest być może rozprawa doktorska Violety Žakevič [2010], do której to pracy [!] nie udało mi się dotrzeć. W zestawie cytowanej literatury nie podaję licznych prac szczegółowych pomijających - jak się okazało - opisywany tu typ zdań względnych.

$4 \mathrm{Na}$ opracowanie to zwróciła moja uwage prof. Lea Sawicki. O różnicach między niniejszym tekstem a tekstem I. Mendozy będzie mowa niżej. 
czyźnie zawiera także artykuł Barbary Citko [2016], w którym wspomina się, że polski dopuszcza zdania takiego typu, co zilustrowano jednym przykładem, używanym w pracach składniowych w różnych wersjach językowych i z różnymi realiami dla zilustrowania omawianego zjawiska składniowego.

(5) Jan należy do Ligi Polskich Rodzin, która to organizacja jest skrajnie prawicowa [Citko 2018, 90].

Oryginalna wersja tego przykładu pochodzi z pracy Jamesa McCawleya [1981] i jest cytowana m.in. przez Guglielmo Cinque [2008]. Zdania $z$ powtórzonym rzeczownikiem, choć niekoniecznie odnoszące się do przynależności do prawicowych ugrupowań, występuja w wielu językach europejskich, m.in. w angielskim, włoskim [Cinque 2008], niderlandzkim, portugalskim [Cardoso, de Vries 2010] i hiszpańskim. Dla hiszpańskiego i francuskiego nie znalazłam potwierdzenia w źródłach lingwistycznych. Niemniej można dość łatwo znaleźć przykłady odpowiednich zdań, np.:

(6) hiszp. En muchos casos, hay una serie de imágenes, una al lado de la otra, la cual cadena indica que todos los eventos comparten la misma importancia histórica y cultural (W wielu wypadkach pojawia się seria rysunków, jeden obok drugiego, który to ciag oznacza, że wszystkie wydarzenia maja to samo znaczenie historyczne i kulturowe) [https://es.wikipedia.org/wiki/C\%C3\%B3dice_Aubin, data dostępu: 15.08.2018, przekład i wyróżnienia własne].

Na ogół zdania tego typu są uważane za należące do stylu książkowego odpowiedniego języka [Cinque 2008; Cardosoi de Vries 2010]. Stanowia one podtyp zdań względnych nierestryktywnych (determinujaccych [sic!] w terminologii R. Grzegorczykowej [2004, 118]). Przy czym, o ile w polskim odróżnienie obu typów zdań względnych $\mathrm{w}$ piśmie na gruncie składniowym nie jest możliwe, jako że nie różnią się ani użytym zaimkiem, ani interpunkcją, o tyle na przykład w językach romańskich i w angielskim tylko zdania nierestryktywne wydziela się przecinkami, a wyborem właściwego zaimka względnego rządzą dość skomplikowane reguły. Co więcej, w języku hiszpańskim i we włoskim, w zdaniach $z$ rzeczownikiem wewnątrz zdania względnego, możliwy jest tylko jeden spośród zaimków pojawiających się w zdaniach nierestryktywnych: odpowiednio il quale we włoskim [Cinque 2008] i el cual w hiszpańskim [Brucart 1999]. Wyrażenia te jako jedyne spośród zaimków względnych w przywołanych językach odmieniaja się przez rodzaj (nie tylko przez liczbę, jak np. hiszpańskie quien), a ich forma rodzajowa akomodowana jest do rodzaju rzeczownika (por. forma żeńska la cual w przykładzie (6)). 
Zdania polskie, o których mowa w niniejszym tekście, choć niewspominane w gramatykach, pojawiaja się w innych źródłach, bez szczegółowego opisu składniowego. Jedno $z$ nich to porada językowa Mirosława Bańki [2013], z której pochodzi przykład (1). Pozostałe opracowania, do których dotarłam, maja charakter leksykograficzny. W Innym słowniku języka polskiego w haśle który czytamy:

Wyrażeniem który to możemy wprowadzić zdanie podrzędne nawiąujące do jednego $z$ rzeczownikowych składników zdania nadrzędnego i rozwijające jego treść. Aby takie nawiazanie było skuteczne, po wyrażeniu który to przytaczamy ów składnik rzeczownikowy lub podajemy określenie, które pozwala go zidentyfikować. Usiadł na kawałku chleba z dżemem, który to chleb dowcipnie położył mu na krześle Heniek... Umowa opiewała na przygotowanie „Praktycznego słownika języka polskiego”, który to tytuł zmieniono później na „Mały słownik języka polskiego... Pracowałem w Zakładach Koksowniczych „Przyjaźn” w Dabrowie Górniczej, z którego to miasta jestem posłem... [ISJP 2002, wyróżnienia oryginalne].

Zdania takie nie są współczesną innowacja. Odnotowuje je - również w haśle który - już Słownik polszczyzny XVI w. (przykład (7)), choć w większości przykładów opisywanego tu zjawiska składniowego pojawia się samo który, bez to, tak jak w przykładzie (8).

(7) miéyże vrzędnégo Kápłaná od Piotrá Rzymfkiego do Polfki poftánégo / który by to Kápłan vrzędny / dał w rece Królowi twemu Miecz / ku obrónie wolności twéy [SPXVI w.].

(8) wnet ná nich pomfta Boża przy złá / iż Srebro i Ołow / które krufzce przed tym w gorach Bitomsskich hoynie kopano / zaraz zginęly y przepadły [SPXVI w.].

Przykłady interesujących nas zdań można znaleźć także w Korpusie Polszczyzny 1830-1918 [Bilińska et al. 2016]:

(9) Według niego np. ochrona, jaka posiadaja zwierzęta klimatu zimnego w grubym $i$ ciepłym swym futrze, powstała głównie dzięki długotrwałemu wpływowi nizkiej temperatury na skóre tych zwierzat, który to bodziec wywołał silniejszy rozrost uwłosienia.

(10) Komitet centralny, uznał nader trafne postepowanie wysłańca swego, a znajdujac się właśnie $w$ coraz większym niedostatku, $z$ téj zwróconéj summy nie był $w$ stanie więcéj nad 5000, do Niemiec przesłać, która to summa była wprost generałowi Bemowi doreczona.

(11) Rzeczka przez Pelplin płynaca nie zowie sie po polsku Ferse, jak mówia Niemcy $i$ choć tak Lelewel pisze, ale się zowie Wierzyca, które to miano żyje po dziś dzień w uściech okolicznego ludu.

Podstawa materiałowa przedstawionych tu rozważań sa cytaty z NKJP. Uwzględniono tzw. korpus pełny, czyli niezrównoważony pod 
względem typu tekstów i ich źródeł. Łacznie znaleziono 291 przykładów. Zdecydowana większość $z$ nich pochodzi $z$ gazet codziennych (głównie z „Dziennika Zachodniego” i „Gazety Poznańskiej”). Teksty są dość niejednorodne tematycznie (strony sportowe, wiadomości lokalne, rzadziej teksty o charakterze popularnonaukowym). Spoza prasy jest zaledwie kilka zaświadczeń. W NKJP stosunkowo mało jest przykładów $z$ języka mówionego. Nie oznacza to jednak, że zdania takie nie występuja w polszczyźnie mówionej. W korpusie polszczyzny mówionej Spokes [Pęzik 2015] znaleziono ponad 30 przykładów (tu nieanalizowanych).

$\mathrm{W}$ badaniach opartych na danych korpusowych problemem metodologicznym jest sprawa oceny poprawnościowej analizowanego materiału. Uznałam, że wszystkie cytowane przykłady sa akceptowalne, choć nie sposób nie zauważyć, że nie we wszystkich przyjęte rozwiązania sa najszczęśliwsze pod względem stylistycznym i można by $z$ nich zrezygnować, wykorzystując konstrukcje $z$ odpowiednimi przysłówkami względnymi [Grzegorczykowa 2004, 122], np. w zdaniu (12) wyrażenie o której to porze można by zastapić przysłówkiem względnym kiedy:

(12) wysoce ukulturalnione programy spycha poza pasmo najwyższej ogladalności, czyli poza 22.00, o której to porze naród zasypia, ponieważ o 6.00 musi się zerwać do roboty [NKJP].

Niemniej, mimo pewnej ciężkości stylu, która powoduje czasami użycie analizowanych konstrukcji, w wielu wypadkach znajduja one funkcjonalne uzasadnienie, tak że diagnozę M. Bańki [2013]: „Wypowiedzenia tak zbudowane sa najzupełniej poprawne, ale nie należy używać ich bez powodu" można rozszerzyć na większość analizowanych wypowiedzeń. Więcej jest też możliwości składniowego nawiązania do treści zdania nadrzędnego. W dalszym toku wywodu przyjrzymy się cechom gramatyczno-semantycznym badanych wypowiedzeń i spróbujemy pokazać, jakimi powodami mogli kierować się ich autorzy, a właściwie, jakie możliwości - w porównaniu $z$ innymi rozwiązaniami - oferują analizowane konstrukcje.

Tym samym niniejszy tekst różni się od wspomnianego wyżej tekstu I. Mendozy [2010], która skupia się głównie na porównaniu zdań względnych $z$ rzeczownikiem wewnętrznym (jądrem wewnętrznym w jej terminologii) ze zdaniami względnymi restryktywnymi i zdaniami względnymi nierestryktywnymi bez powtórzonego rzeczownika.

\section{ANALIZA MATERIALU}

Przegląd danych korpusowych pozwala na dokonanie obserwacji dwóch rodzajów. Część $z$ nich potwierdza informację leksykograficzna z ISJP, a część ją rozszerza. 
W opisywanych tu zdaniach rzeczownik wewnatrz zdania względnego może być powtórzeniem rzeczownika ze zdania nadrzędnego (o czym wspominano w cytowanym wyżej haśle $z$ ISJP; por. także Topolińska [1984] i Mendoza [2010]). Dzieje się tak często wtedy, gdy odniesienie zaimka względnego który byłoby niejednoznaczne. Jedną z przyczyn takiej niejednoznaczności jest sytuacja, gdy rzeczownik zdania nadrzędnego jest nadrzędnikiem grupy nominalnej zawierającej inne rzeczowniki o tej samej charakterystyce liczbowo-rodzajowej (13). Co prawda odpowiednia reguła poprawnościowa pozwala na to, by zaimek który odnosił się nie do bezpośrednio poprzedzającego go rzeczownika, ale także do rzeczownika, na który w zdaniu nadrzędnym pada akcent logiczny, niemniej ustalenie zamierzonego przez nadawcę miejsca akcentu logicznego piśmie jest często niemożliwe:

(13) To rozwiazanie w zasadniczym stopniu może zniweczyć cała koncepcje reformy ubezpieczeń społecznych, na która to koncepcje państwo sie zdecydowało [NKJP].

Bez powtórzonego rzeczownika w przykładzie (13) zaimek który mógłby odnosić się zarówno do rzeczownika koncepcja, jak i do rzeczownika reforma.

Rozwiazanie polegające na powtórzeniu rzeczownika jest częste, gdy grupa nominalna, do której nadrzędnika ma odnosić się zdanie względne, jest bardzo rozbudowana prawostronnie:

(14) Od Rosz haSzana rozpoczyna się dziesięciodniowy okres połaczonego $z$ pokuta rozrachunku Żydów z własnym sumieniem i z Bogiem, który to okres zamyka święto Jom Kippur [NKJP].

(15) (...) byt on autorem rewolucyjnego wynalazku: nakręcania zegarków nie za pomoca kluczyka lecz ruchomej główki, który to wynalazek - opatentowany - przetrwał jak wiemy długie lata [NKJP].

Druga sytuacja powodująca niejednoznaczność odniesienia zaimka który zwiazana jest synkretyzmem jego form fleksyjnych. Przy pewnych wartościach kategorii przypadka możliwe sa różne odniesienia tego zaimka, co ilustruje przykład (17), stanowiący modyfikację oryginalnego przykładu korpusowego (16), w którym dzięki powtórzeniu tej niejednoznaczności nie ma. W rezultacie (16) jest poprawne, a (17) - nie.

(16) Tu zabawne wspomnienie - ojciec dostał przydział mieszkania, na którym to przydziale napisane było „inżynier Polak”, nazwa osiedla - i... klamke [NKJP].

(17) *Tu zabawne wspomnienie - ojciec dostał przydział mieszkania, na którym napisane było „inżynier Polak”, nazwa osiedla - i... klamkę. 
W niektórych wypadkach, jeżeli synkretyczna forma zaimka który jest podmiotem zdania względnego, jednoznaczną interpretację narzuca akomodowana pod względem np. liczby forma czasownika, tak jak w przykładzie (30), analizowanym w dalszej partii tekstu, gdzie bez rzeczownika wewnętrznego zdanie będzie jednoznaczne. ${ }^{5}$

W pewnych sytuacjach zachodzi konieczność powtórzenia całej frazy nominalnej, np. gdy zdanie nadrzędne zawiera skoordynowane dwie frazy nominalne o tym samym (powtórzonym) nadrzędniku, a zdanie względne odnosi się tylko do jednej z nich, np.:

(18) Pochylity się z troska nad rzekomym brakiem edukacji seksualnej $i$ brakiem pieniędzy na środki antykoncepcyjne (który to brak pieniędzy nie przeszkodził małżeństwu w postawieniu domu) [NKJP].

Rzeczownik wewnątrz zdania względnego może jedynie wskazywać na odpowiedni rzeczownik zdania nadrzędnego, nie będąc jednak jego powtórzeniem, o czym również wspomniano w odpowiednim haśle ISJP [por. także Mendoza 2010]. W takich konstrukcjach często w zdaniu względnym pojawia się pojęcie ogólniejsze niż w zdaniu nadrzędnym, ale nie zawsze typowy hiperonim, chociaż takie rozwiąanie jest stosunkowo częste (przykłady19-20):

(19) Jedna z największych atrakcji była niewatpliwie loteria fantowa, w której można było wylosować żywa kure czy okazałego gołębia, które to ptaki przekazali mieszkańcy wsi [NKJP].

(20) Objawia sie to charakterystycznym bólem w okolicach mostka (często promieniujacym do lewego ramienia) oraz zadyszka, które to objawy występuja szczególnie podczas wysiłku, kiedy serce potrzebuje więcej tlenu [NKJP].

Wykorzystywane są także inne typy relacji wskazujących na koreferencje [por. Ogrodniczuk et al. 2015]. Często dotyczy to dat, kwot, liczb, tak jak w przykładzie (21):

(21) Gminna propozycja zakłada, że w przypadku 85-procentowej ściagalności czynszów daje to ok. $8 \mathrm{mln}$ zl miesięcznie, $z$ których to pieniędzy dopłacałaby ona do czynszów lokatorów najbiedniejszych mieszkajacych $w$ zasobach prywatnych [NKJP].

W odniesieniu do innych typów informacji niesionych przez rzeczownik zdania nadrzędnego można znaleźć interesujące przykłady wykorzystania relacji semantycznej parametr - wartość parametru

5 Rozwiązywanie ewentualnej dwuznaczności odniesienia zaimka względnego podmiotowego na podstawie wartości formy czasownikowej nie jest ograniczone wyłącznie do polszczyzny [zob. Linde-Usiekniewicz, Szewczyk 2013]. 
[por. Padučeva 1999]. ${ }^{6}$ Sa one o tyle ciekawe, że możliwa jest zarówno sekwencja, w której w zdaniu głównym występuje wartość parametru, a w zdaniu względnym parametr (22), jak i taka, gdzie w zdaniu głównym występuje parametr, a w zdaniu względnym - jego wartość (23):

(22) (...) z biegiem lat funkcje redagowania gazety schodzity na plan dalszy, ustępujac zadaniom przynależnym prezesowi, która to funkcje jednocześnie piastowałem [NKJP].

(23) Wczoraj burmistrz Rio de Janeiro oddał klucze do miasta „królowi karnawału”, która to funkcje pełni najcięższy uczestnik blisko pięciodniowej zabawy [NKJP].

Wiele przykładów $z$ rzeczownikiem nawiąującym realizuje schemat, w którym w zdaniu nadrzędnym pojawia się nazwa własna, a w zdaniu względnym nazwa pospolita, np.:

(24) [nie] może uzyskać obywatelstwa polskiego na podstawie ustawy o repatriantach, ponieważ nie ma polskiego pochodzenia i jest obywatelka Białorusi, którego to kraju ustawa o repatriantach nie dotyczy [NKJP].

Czasami zabieg taki pozwala na dookreślenie konkretnego odniesienia nazwy własnej: w przykładzie (25) nazwa Southampton nie odnosi się do miasta w Anglii, lecz do klubu piłkarskiego z siedzibą w tym mieście:

(25) Obaj spotkali sie ponownie przed miesiacem już $w$ Southampton, $z$ którym to klubem Polak podpisal kontrakt do czerwca 2008 roku [NKJP].

Kolejną możliwością, która oferuje użycie rzeczownika nawiąującego, jest przejście $z$ języka przedmiotowego na poziom metajęzykowy, jak w przykładzie (1). Dotyczy to zarówno rzeczowników pospolitych (26), jak i nazw własnych (27). Możliwe, choć rzadsze, jest również przejście $z$ poziomu metajęzykowego na poziom języka przedmiotowego, tak jak w przykładzie (28):

(26) (...) skład Rady Polityki Pieniężnej: gołębie, czyli osoby dażace do maksymalnej redukcji stóp podatkowych, czy też jastrzębie, którym to

6 Różnicę tę ilustruje para przykładów zaczerpniętych $z$ prac autorki. Tak na przykład w zdaniu Trzeba wyznaczyć termin spotkania słowo termin powinno być interpretowane jako wprowadzajace jedynie parametr, a nie jego wartość, gdyż ze zdania tego nie wynika, czy jakiś termin został ustalony. $Z$ kolei w zdaniu Wyznaczono spotkanie na piatek fraza na piątek realizuje wartość tego parametru, natomiast sam parametr pozostaje domyślny. Brak miejsca nie pozwala na szczegółowe omówienie przywołanej pracy. 
przydomkiem obdarzano ludzi nie tylko sceptycznie nastawionych do radykalnych obniżek, ale bardzo ostrożnych $w$ wyrażaniu zgody na każda redukcje [NKJP].

(27) W najdawniejszych czasach Dendera była miejscem przebywania jak $i$ stacjonowania Hathor, pod którym to imieniem kryła się nie bogini, lecz straszliwa bron boga słonca Tota [NKJP].

(28) Będzie to „Ballada o Zakaczawiu”, która to nazwe nosi „przeklęta" dzielnica Legnicy [NKJP].

W pewnych wypadkach identyfikację umożliwia szerszy kontekst, a bez niego czytelnik musi odpowiednią informację uzupełnić na podstawie rzeczownika w zdaniu względnym, np.:

(29) Obecnie pracujemy nad kościołami dzielnic spoza śródmieścia, który to tom zamykałby część poświęcona obiektom sakralnym miasta [NKJP],

gdzie sygnałem, że chodzi o opracowanie naukowe poświęcone budowlom sakralnym, a nie na przykład o renowację, jest rzeczownik tom.

Konstrukcje $z$ rzeczownikiem nawiąującym do rzeczownika w zdaniu nadrzędnym pozwalają na uniknięcie ewentualnych dwuznaczności związanych $z$ grupami współrzędnymi w nadrzędnikach zdań względnych [por. Gębka-Wolak 2015]: ${ }^{7}$

(30) (...) to przeczy skromności, pokorze i zachowaniu ubóstwa, które to cechy powinny zwłaszcza przynależeć osobom duchownym [NKJP].

Choć, jak wspomniano wyżej, w zdaniu tym liczba mnoga czasownika wyjaśnia, że chodzi nie tylko o ubóstwo, ale przynajmniej także o pokorę.

Najciekawszą własnościa analizowanych w tej części wywodu zdań jest to, że rzeczownik wewnattrz zdania względnego nie musi nawiazywać do rzeczownika w zdaniu głównym, lecz do treści całego zdania. W takich wypadkach rzeczownik w zdaniu względnym jest nazwa sytuacji opisanej w zdaniu nadrzędnym - derywowana od czasownika lub nie - albo odnosi się do treści tego zdania w inny sposób:

(31) Najmłodsi uczestnicy fragment prozy mogli zastapić wierszem, $z$ której to możliwości wielu uczniów skorzystało [NKJP].

(32) Najczęściej zazdrościmy innym sukcesów, awansów, pieniędzy, fortuny, urody, powodzenia u kobiet lub mężczyzn, która to zazdrość przechodzi czasami $w$ patologiczny stan zwany syndromem Otella [NKJP].

7 Autorka zajmuje się grupami współrzędnymi połączonymi spójnikiem lub w tekstach prawnych, ale samo zjawisko jest chyba szersze i dotyczy także spójników $i$ oraz czy, a także innych typów tekstów. 
(33) Jest także mistrzem Polski w kata i wicemistrzem w kobudo, które to sukcesy osiagną podczas zawodów rozgrywanych $w$ Oświęcimiu [NKJP].

(34) Konstytucja RP stanowi: Rodzice maja prawo do wychowania dzieci zgodnie $z$ własnymi przekonaniami, a która to myśl dokładniej jeszcze formułuje zapis Powszechnej Deklaracji Praw Człowieka [NKJP].

Informację o innych niż rzeczownikowe i zdaniowe antecedensach zdań względnych wprowadzanych przez któr- to w dawnej polszczyźnie znaleźć można we wspomnianym już Słowniku polszczyzny XVI w.:

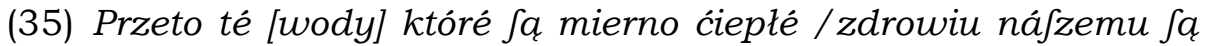
nalepfzé: którégo to ćiepłá iefli co w nich niedoftawa / łátwiéy dowcip $w$ kotle przyczyni [SPXVI w., uzupełnienie oryginalne].

W materiale NKJP znaleziono tylko jeden taki przykład:

(36) (...) a współszafarzami - bp Bronisław Dembowski, dotychczasowy biskup włocławski, bp Jan Bernard Szlaga, biskup pelplinski $z$ której to diecezji wywodzi się nowy ordynariusz włocławski (...).

\section{ZAKOŃCZENIE}

Przedstawiony tu wstępny opis zdań względnych $z$ rzeczownikiem wewnętrznym pozwolił na zaobserwowanie pewnej liczby związanych z nimi zjawisk. Co ważniejsze, samo ich dostrzeżenie i opisanie powinno wzbogacić istniejace opisy składniowe polszczyzny. Ważna cecha formalno-składniowa tych zdań jest to, że pokazuja one, iż odmienny przez liczbę i rodzaj wykładnik zdania względnego może być akomodowany w zakresie wartości tych kategorii gramatycznych wyłącznie do rzeczownika stanowiącego składnik zdania względnego. Cechę taką obserwujemy także w innych językach, w których odpowiedni zaimek może być akomodowany pod względem liczby i rodzaju, np. we włoskim i hiszpańskim (por. przykład (6)).

Najprawdopodobniej inaczej niż w innych językach europejskich, dla których takie zdania względne opisano, nie sa one ograniczone ani do odmiany pisanej, ani do stylów intelektualnych polszczyzny. Zaświadczone sa w korpusie tekstów mówionych, choć nie analizowaliśmy szczegółowo pochodzących z korpusu Spokes cytatów. Wydają się jednak charakterystyczne dla tekstów dziennikarskich. Nasza kwerenda, ograniczona do korpusu niezrównoważonego, nie pozwala jednak na żadne wiarygodne hipotezy ilościowe. 
Ogląd materiału pokazuje, że wstępna klasyfikacja $z$ ISJP pomija pewien typ zdań $z$ rzeczownikiem wewnętrznym. Mamy na myśli zdania $z$ antecedensami innymi niż rzeczownikowe. Ze względów formalnych zatem należałoby zdania $z$ rzeczownikiem wewnętrznym podzielić na $z d a-$ nia $z$ antecedensem rzeczownikowym i nierzeczownikowym, a wśród tych pierwszych dodatkowo wyodrębnić zdania $z$ rzeczownikiem powtórzonym i niepowtórzonym (nawiazującym).

Wspólne dla wszystkich szczegółowych typów opisanych tu zdań $z$ antecedensem rzeczownikowym (zarówno $z$ powtórzonym rzeczownikiem, jak i z rzeczownikiem nawiazujacym) jest jednoznaczne wskazywanie, iż zdanie względne jest zdaniem nierestrykcyjnym. Analogiczna funkcję może pełnić zastąpienie zaimka który wyrażeniem któr- to, jak w przykładzie (2), ale nie zawsze jest to rozwiązanie szczęśliwe. Sytuację taką ilustruje przykład (37):

(37) Poprzez swoje ciepło i głębokie brzmienie radio lampowe pozwala na chwile zastanowienia nad różnorodnościa sposobów ujarzmiania fal radiowych, które to fale były przed naszym pojawieniem i będa jeszcze długo po nas... [NKJP].

W przykładzie tym mamy powtórzony w zdaniu względnym rzeczownik ze zdania nadrzędnego (fale). Rezygnacja $z$ tego rozwiązania spowodowałaby niejednoznaczność, w wyniku której zdanie dopuszczałoby interpretację restrykcyjna, zgodnie $z$ która treść zdania względnego zawężałaby zakres odniesienia frazy fale radiowe. Treść zdania głównego odnosiłaby się wtedy wyłącznie do fal radiowych poprzedzajacych pojawienie się rodzaju ludzkiego oraz istniejących po jego wyginięciu, tak jak w przykładzie (37'):

(37') ?Poprzez swoje ciepło i głębokie brzmienie radio lampowe pozwala na chwile zastanowienia nad różnorodnościa sposobów ujarzmiania fal radiowych, które były przed naszym pojawieniem i będa jeszcze długo po nas...

Równie niezręczne byłoby tu wykorzystanie wyrażenia któr- to bez rzeczownika wewnętrznego:

(37") ?Poprzez swoje ciepło i głębokie brzmienie radio lampowe pozwala na chwile zastanowienia nad różnorodnościa sposobów ujarzmiania fal radiowych, które to były przed naszym pojawieniem $i$ będa jeszcze długo po nas...

Zastosowanie zdań względnych $z$ rzeczownikiem wewnętrznym jest - jak już wielokrotnie wspomniano - strategia pozwalajaca na uniknięcie potencjalnej niejednoznaczności. Dotyczy to także zdań względnych 
$z$ antecedensem zdaniowym: ich przekształcenie w zdania podrzędne rozwijające wprowadzane przez co albo narzuca przeorganizowanie zdania podrzędnego, albo prowadzi do niejednoznaczności. Pierwsza sytuację ilustruje przykład (38), stanowiący wynik próby przekształcenia zdania (31), a druga przykład (39), powstały z przekształcenia zdania (32). W zdaniu (39) możliwa jest zarówno interpretacja, zgodnie $z$ która oba tytuły zostały zdobyte na zawodach w Oświęcimiu, jak i interpretacja, że na tych zawodach zdobyty został jedynie tytuł wicemistrza w kobudo.

(38) Najmłodsi uczestnicy fragment prozy mogli zastapić wierszem, co wielu uczniów zrobiło // na co wielu uczniów się zdecydowato [część zmodyfikowana wytłuszczona].

(39) Jest także mistrzem Polski $w$ kata $i$ wicemistrzem $w$ kobudo, co osiagną podczas zawodów rozgrywanych w Oświęcimiu.

Można by oczekiwać, że część analizowanych zdań będa stanowić zdania, które R. Grzegorczykowa nazywa rozwijajacymi lub pozornie względnymi. Zdanie takie "nie zawiera (...) charakterystyki desygnatu rzeczownika, z którym się łączy, ale informuje o kolejnym zdarzeniu" [Grzegorczykowa 2004, 118]. Niemniej w badanym materiale nawet zdania względne w czasie przyszłym, odnoszace się do wydarzeń, które dopiero maja nastapić [por. Loock 2007, 340-344] służyły wzbogaceniu charakterystyki desygnatu rzeczownika, niezależnie od tego, czy mamy do czynienia $z$ rzeczownikiem ze zdania nadrzędnego powtórzonym w zdaniu względnym (40), czy rzeczownikiem nawiązujaccym (41-42):

(40) Środowisko sędziowskie mówi, że chodzi o „zwrócenie uwagi społeczeństwa i rzadzacych na problemy wymiaru sprawiedliwości”, które to problemy moga wkrótce ograniczyć obywatelom prawo do sadu [NKJP].

(41) Poznańskie zawody potraktowaliśmy jako sprawdzian generalny przed kwalifikacjami olimpijskimi do igrzysk $w$ Atenach, która to impreza odbędzie się na przełomie listopada i grudnia $w$ Paryżu-dodat Robert Sadurski, trener polskiej reprezentacji [NKJP].

(42) (...) sa jeszcze jakieś punkty zapalne, na przykład podwójne nazwy miejscowości, czy niemiecki jako pomocniczy język urzędowy, które to nowości być może wprowadzi ustawa o mniejszościach narodowych $i$ etnicznych (...) [NKJP].

Warto odnotować jednak, że zdecydowana większość zdań względnych pojawiała się na końcu zdania złożonego, którego część stanowiły. Większość wyjątków to sytuacje, w których jakaś grupa nominalna $\mathrm{w}$ obrębie zdania względnego opisywana była kolejnym zdaniem względnym. 
Kolejną ciekawą własnościa - ale już tylko zdań względnych z rzeczownikiem nawiąującym do zdania nadrzędnego - jest możliwość formułowania zdań względnych o charakterze subiektywnej oceny [Loock 2007], przy czym inaczej niż w przykładach tej autorki, w naszym materiale ocena taka wyrażona była także przez dobór nawiązujaccej frazy rzeczownikowej, np.:

(43) Chodzi przede wszystkim o podatek obrotowy i minimum socjalne, które to projekty ludyczne mają wymiar księżycowy [NKJP].

W przykładzie tym nie tylko orzeczenie zdania względnego (maja wymiar księżycowy) jest nośnikiem oceny podatku obrotowego i minimum socjalnego, ale także przymiotnik ludyczny określający te projekty.

Jak wskazuje tytuł niniejszego tekstu, przedstawione tu uwagi stanowia jedynie wstępne rozpoznanie zjawiska. Dalsze kroki badawcze powinny iść w dwóch kierunkach. Po pierwsze, na rozważenie zasługuje status wyrażenia który to, i to zarówno w analizowanych tu zdaniach, jak i w zdaniach względnych bez rzeczownika wewnętrznego, takich jak (2). W szczególności trzeba odpowiedzieć na pytanie, czym jest w takim wyrażeniu segment to (por. przypis 2.). Po drugie, przedstawione tu obserwacje ograniczyły się do wybranych kwestii. Otwarta pozostaje sprawa analizy roli zdań względnych $\mathrm{z}$ rzeczownikiem wewnętrznym w większych jednostkach tekstowych.

\section{Bibliografia}

M. Bańko, 2013, Porada z dnia 5.12.2013, https://sjp.pwn.pl/poradnia/haslo/ ktory-to;14742.htm [data dostępu: 12.08.2019].

J. Bilińska, M. Derwojedowa, M. Kwiecień, W. Kieraś, 2016, Mikrokorpus polszczyzny 1830-1918, „Komunikacja Specjalistyczna / Communication for Special Purposes" 11, s. 149-161.

J. Brucart, 1999, La estructura del sintagma nominal: Las oraciones de relativo [w:] I. Bosque, V. Demonte (red.), Gramática Descriptiva de la Lengua Española, Madryt, s. 395-522.

J. McCawley, 1981, The Syntax and Semantics of English Relative Clauses, „Lingua" 53, s. 99-149.

A. Cardoso, M. de Vries, 2010, Internaland External Headsin Appositive Constructions, https://pdfs.semanticscholar.org/f16b/3abcd0d130b43eda706 5d37a28cc2377be13.pdf [data dostępu: 10.08.2018].

G. Cinque, 2008, Two types of non-restrictive relatives [w:] O. Bonami, P. Cabredo Hofherr (red.), Empirical Issues in Syntax and Semantics 7, s. 99-137.

B. Citko, 2016, Types of Appositive Relative Clauses in Polish, „Studies in Polish Linguistics" $11 / 3$, s. 85-85. 
M. Gębka-Wolak, 2015, „Podatnik lub płatnik, który..., wypadku lub choroby, których...”. Zdania względne rozwijajace konstrukcje wspótrzędne ze spójnikiem lub $w$ tekstach prawnych - budowa a interpretacja, „Kwartalnik Sadowy Apelacji Gdańskiej” IV, s.143-164.

R. Grzegorczykowa, 2004, Wykłady z polskiej składni, Warszawa.

ISJP 2002: M. Bańko (red.), 2002, Inny słownik języka polskiego, Warszawa.

Z. Klemensiewicz, 1953, Zarys składni polskiej, Warszawa.

J. Linde-Usiekniewicz, E. Szewczyk, 2013, Sobre la potencial ambigüedad de los antecedentes de las relativas [w:] E.Waluch-de la Torre, J.A. Antonio Moya Corral (red.), Español hablado. Estudios sobre el corpus PRESEA-GRANADA, Warszawa.

R. Loock, 2007, Appositive relative clauses and their functions in discourse, „Journal of Pragmatics" 39, s. 336-362

I. Mendoza, 2010, Relativsätzemit który to, „Wiener Slawistischer Almanach” 65 , s. $105-118$.

M. Ogrodniczuk, K. Głowińska, M. Kopeć, A. Savary, M. Zawisławska, 2015, Coreference: annotation, resolution and evaluation in Polish, Berlin.

E. Padučeva, 1999, Metonimičeskie i metaforičeskie perenosy v paradigme glagola naznačit' [w:] E. Raxilina, Y. Testelec (red.), Typology and the Theory of Language: From Description to Explanation, Moskva, s. 488-502.

P. Pęzik, 2015, Spokes - a Search and Exploration Service for Conversational Corpus Data [w:] Linköping Electronic Conference Proceedings, Linköping, s. 99-109.

A. Przepiórkowski, A. Kupść, M. Marciniak, A. Mykowiecka, 2002, Formalny opis języka polskiego: teoria i implementacja, Warszawa.

SPXVI: Słownik polszczyzny XVI wieku, wersja cyfrowa, https://spxvi.edu.pl/ wersja-cyfrowa [data dostępu: 10.08.2018].

A. Stypka, 1995, Zdania przydawkowe $w$ różnych stylach funkcjonalnych wspótczesnej polszczyzny, „Poradnik Językowy” z. 1, s. 5-30.

Z. Topolińska, 1984, Składnia grupy imiennej [w:] Z. Topolińska (red.), Gramatyka współczesnego języka polskiego. Składnia, Warszawa, s. 301-389.

L. Zawadowski, 1952, Zagadnienia teorii zdań względnych, Wrocław.

V. Žakevič, 2010, Zdania złożone z relatywem „który” we współczesnej polszczyźnie, praca doktorska, maszynopis.

\section{Double-headed relative clauses in Polish. A preliminary examination}

\section{Summary}

This paper discusses the so-called double-headed relative clauses in Polish, introduced by a special relator który to, which in sentences bearing such clauses obligatorily agrees with the internal head. Such clauses have been hitherto overlooked in most syntactic descriptions of Polish. The inquiry is based on 291 citations obtained from the National Corpus of Polish, analysed for their semantic and syntactic features. The results show that double-headed relative clauses in 
Polish are marked as explicitly non-restrictive (as opposed to standard relative clauses). While identical internal and external heads need to be separated by a phrase governed by the external head, there is no such constraint on nonidentical internal heads. These may have not only nominal, but also clausal antecedents. In addition, non-identity of internal and external heads allows an introduction of subjective valuation (in the internal head) and a switch from object language to metalanguage or vice versa between the governing clause and the relative clause.

Adj. Monika Czarnecka 